\title{
Study on behavioural ecology of Ditomus calydonius Rossi, 1790 (Coleoptera: Carabidae: Ditomina), a strictly granivorous ground beetle with brood care
}

\section{Изучение особенностей поведения Ditomus calydonius Rossi, 1790 (Coleoptera: Carabidae: Ditomina), зерноядной жкужелиџы с заботой о потомстве}

\author{
Pietro Brandmayr ${ }^{1}$, Federica Talarico ${ }^{2}$ \\ Пьетро Брандмайр ${ }^{1}$, Федерика Таларико ${ }^{2}$
}

\footnotetext{
${ }^{1}$ University of Calabria, Department of Biology, Ecology and Earth Sciences, 87036 Rende (CS). Italy. E-mail: brandmayr@unical.it

2 Natural Museum and Botanical garden, University of Calabria, 87036 Rende (CS). Italy. E-mail: federica.talarico@unical.it
}

KEY WORDS: habitat selection, phenology, reproduction rhythms, life cycles, brood care, subsocial behaviour. КЛЮЧЕВЫЕ СЛОВА: выбор среды обитания, фенология, репродуктивный ритм, жизненный цикл, забота о потомстве, субсоциальное поведение.

ABSTRACT The ecology of Ditomus calydonius is investigated mainly in the field, to define the poorly known habitat choice, the seasonal and reproduction rhythm, the circadian activity rhythm, the relationships with the food plant, Daucus spp. and the nesting behaviour. After pitfall-trapping of 120 sites in Calabria, the preferred habitat is found in open land on clayey soil, where this species lives stenotopic especially on southern-aspect slopes. The population activity is remarkable for its late onset in the year (June), strictly nocturnal daily rhythm, possible intrahabitat micromigration from early flourishing Daucus plants to later ripening patches. Short data concerning foraging/feeding behaviour, shape of the only one nest found in nature and ability and time of flight are presented. Some data concerning laboratory behaviour and nesting have been added. Territorial combatative interaction between males, hitherto rarely observed in Carabidae, has discovered in this species for the first time.

РЕЗЮМЕ. Изучение экологии Ditomus calydonius Rossi, 1790 преимущественно в полевых условиях, внесло ясность в биотопические предпочтения вида, типы его сезонного, репродуктивного и циркадного ритмов, во взаимосвязь с пищевым растением (Daucus spp.), а также особенности гнездового поведения. По результатам учётов почвеными ловушками на 120 модельных участках в Калабрии установлено, что данный стенотопный вид предпочитает открытые местообитания с глинистой почвой, особенно расположенные на южных склонах. Для данного вида характерны позднее начало напочвенной активности (в июне), ночной суточный ритм, а также микромиграции в пределах одного и того же местообитания с участков с рано цветущими кормовыми растениями на участки с растениями, созревающими позднее. Приведены краткие сведения о фуражировочном и пищевом поведении, строению единственного обнаруженного в природе гнезда, а также полётных способностях и времени лёта. Получены дополнительные данные о гнездовом поведении в лаборатторных условиях. У самцов $D$. calydonius впервые обнаружены бои за территорию, редко наблюдаемые у Carabidae.

\section{Introduction}

The Ditomina are a carabid group restricted to the mediterranean Old-World and to the centralasian steppes and of considerable interest for many unusual aspects of their morphology, phylogeny and eco-ethology. About hundred years ago Stichel [1923] identified the ditomines as a separate Harpaline subtribe of recent Miocene origin, arising from Ophonus-like ancestors. Recently, descriptions of the larvae revealed atypical morphology and habits, which are considered aberrant [Sharova, 1958, 1960 for Chilotomus tschitscherini Semenov, 1903; Brandmayr, 1975, for Ditomus calydonius Rossi, 1790; Sharova, Makarov, 1983, for Machozetus lehmanni Ménétriés, 1848]. In fact, the only three genera described show blind and physogastric larvae, poorly

How to cite this article: Brandmayr P., Talarico F. 2021. Study on behavioural ecology of Ditomus calydonius Rossi (Coleoptera: Carabidae: Ditomina), a strictly granivorous ground beetle with brood care // Russian Entomol. J. Vol.30. No.4. P.455-467. doi: 10.15298/rusentj.30.4.08 
adapted to autonomous locomotion and very similar to those of scarabaeoid beetles. The following adult-larva

$$
\text { Adults }
$$

pro-mesothorax articulation slender, prothorax heavy and with advanced barycentre, according to improved digging ability and forebody movements allowing easier climbing on herbaceous plants and seed transport ("scaritoid" habitus)

sexual dimorphism improved, males often with cephalic protuberances on clypeus and mandibles, characterized by allometric growth progression (Fig. 1, possible use in intermale combats, see e.g. Crowson [1981], for other Coleoptera) comparison elucidates the most important adaptational features of the Ditomini:

Larvae

reduction or full rudimentation of cerci, normally present in campodeiform larvae, reduction of the pygopodium, improved spine rows on legs for digging in hard soils, lateral ocelli and sensorial vesicle of the 3rd antennomere completely reduced

physogastric (abdomen-enflated) body, more or less Cshaped (scarabaeiform)

inversion of the size relationships among sexes, males usually larger than females (Fig. 1)

The discovery of the first nest of $D$. calydonius, found July 1973 on the Tremiti Islands (Southern Adriatic) by Brandmayr and Brandmayr Zetto [1974] demonstrated that also Adephagan Coleoptera are able to nurse the offspring through the entire prae-imaginal life, in paedotrophic nests supplied with seeeds of Daucus gingidium as food for the young. Adult beetles also fed on the same umbel plant. The short time devoted to observations allowed clarify at least some fundamental points: a) brood care done by the mother until the offspring is adult (in the Tremiti nest a total number of 26 offspring was recorded); b) paedotrophic nests are provisioned by the mother; c) ripe seeds of $D$. gingidium (in July the most plants were "brown"); d) the existence of many "new born" families around August 15 , as in a spring breeder (new generation adults crowded at certain points in the habitat); e) seeds of $D$. carota were also accepted; f) the habitat, given by natural garigues and other kinds of also man-made open land.

The question of food supply in mainland Italy for this species has considered important because on the Tremiti Islands ripe, brown coloured Daucus gingidium umbels are commonly available from July, whereas in continental Italy the normal ripening time of Daucus is September. This would appear too late to allow the provisioning of a nest from which the new generation normally emerges no later than early September. In fact, no ripe Daucus plants are found in the habitat of $C$. calydonius on the Italian mainland before August or September, so how could the females supply the nests with ripe seeds or seeds at all? Another unknown aspect of nest provisioning is whether nests are stocked with a complete supply of seeds at the beginning of breeding or are provisioned on daily basis.

Important sociobiological questions are mainly unanswered. Do males cooperate with females in nest digging? More generally speaking, where does the observed brood care exhibited by this carabid fit within the general theory of social development in insects [Wilson, 1971, 1979] and in Coleopterans [Crowson, 1981]? In a short review of presocial evolution in Coleoptera, Brandmayr [1992] assigned provisionally the paedotrophic nests of Ditomus to the "nursing of the offspring" level, where probably interaction exists between parents and offspring, even though temporal generation overlapping has not

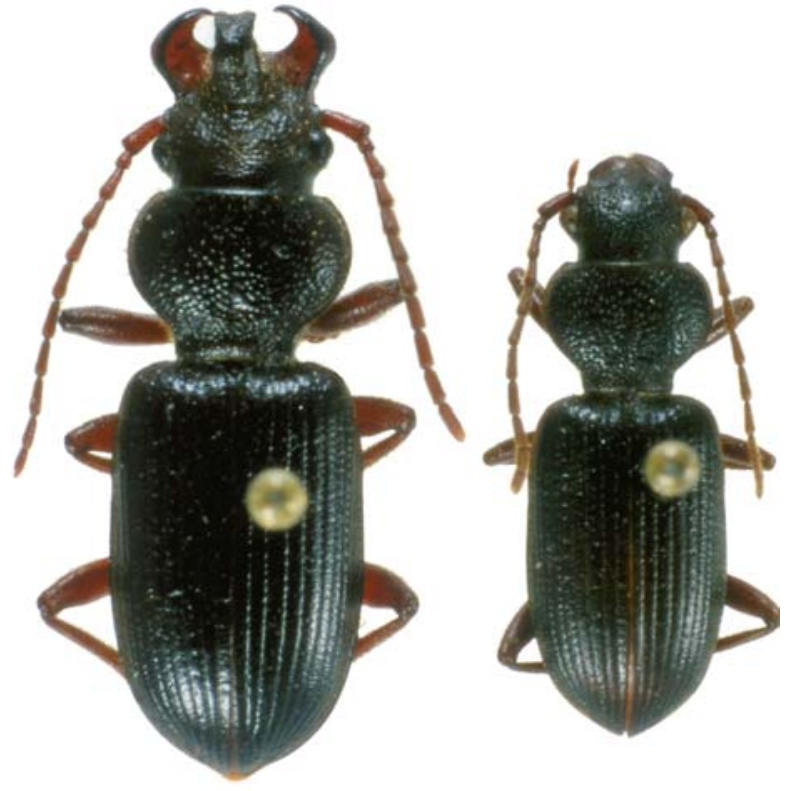

Fig. 1. Male (left) and female (right) of D. calydonius, dark coloured sexually mature adults. Note the outstanding sexual dimorphism.

Рис. 1. Самец (слева) и самка (справа) D. calydonius, половозрелые взрослые особи тёмного цвета (обратите внимание на выраженный половой диморфизм).

clearly demonstrated in this species. A study on the developmental parental care of an Adephagan coleopteran stock looks of high scientific interest, because at the moment generation overlapping is known only in Polyphagan beetle stocks, e.g. in burying beetles Nicrophorus [Pellissier-Scott 1990], or in the Passalidae, where cooperative nursing is also known [Reyes-Castillo, Halffter, 1984]. An exhaustive overview of presocial behaviour in Insects is given by Eickwort [1981], who assignes Dixus Billberg, 1820 behaviour to "parental care based on nests" (subsocial nesting).

Here, we report the results of further investigations in the Calabria region of Italy on habitat choice, bionomy and behaviour of this species, which is not uncommon in the open landscapes of southern peninsular Italy, although the most collectings refer to isolated individuals. The aim was to provide information regarding: 
a) habitat affinity and environmental key factors, especially of the soil: for this part of the study a larger area was investigated;

b) life cycle and phenology of the population, in relation to the seasonal availability of the host plant: for this more detailed study a smaller area was chosen;

c) the role of the male in digging the nest and rearing the young, as well as male competition, mating behaviour and the possible feeding strategy.

Some results of this study were recently summarized in Zetto Brandmayr et al. [1994], and in Brandmayr et al. [1994].

Among habitat features, we focused the investigation mainly on some soil characteristics, because older authors reported that most ditomines show a strong preference for clayey soils [Brulerie, 1873; Antoine, 1959].

\section{Material and methods}

\section{Study areas and climate}

The areas chosen for this study have subdivided in a major one, the area of "habitat" study, and in a smaller, that of "population" study. The first one is given by a more or less linear sequence of collecting stations scattered along a transect of about $70 \mathrm{~km}$ lenght, that crosses Calabria from West to East, that means from the Thyrrhenian Sea to the Jonian. The transect crosses two mountain ranges, the Coastal Chain and the Sila Upland, which reaches nearby 2000 metres height. The habitat types sampled were natural or subnatural forests (Quercus, Fagus, Pinus), clearings, pastures, abandoned croplands, river banks, tree plantations (pine, Eucalyptus), olive growths, and are marked by a wide variety of soil and substrate types, from true limestone to granite, metamorphic rocks, clays, regosols and vertisols. The soils of the investigated biotopes (120) were ranked in seven classes of clay-content or richness of the fineearth component, because punctual clay content analyses are very difficult to relate to the real availability of nest digging sites in a biotope. The "classes of clay richness" are ordered as follows:

1) soils with no clay content at all (granitic, coarse granitic sand, gravels, etc.);

2) clay content very low, less than $10 \%$ (organic soil, or stony skeleton volume prevailing);

3 ) clay content low, maximally $20 \%$, often distributed in pockets or patches, e.g. "terra rossa" in karstic land or other limestone habitats;

4) medium clay content, less than $50 \%$ of the fine fraction;

5) Sites with at least patches of high clay content, over $70 \%$ of the fine fraction.

6) Sites with pure clay or very clay-rich bedrocks, mostly characterized by winter solifluction and vertic structure;

7) Pure clay bedrocks more or less rich in sodium chloride, given in Calabria by Pliocene sediments (socalled blue clays, marked by heavy solifluction and erosion often evolving in typical "badlands" called calanchi).
The "population study" area is located on the hills of the Crati Valley near Cosenza, Calabria (Southern Italy), not far from the new buildings of the University of Calabria (Arcavacata, municipality of Rende near Cosenza). It corresponds to site Ar4 of the above described transect, where 1989-1990 an activity density level of 0.064 individuals/trap over $10 \mathrm{~d}$ has been measured, the second highest value found by the first author in an italian site. Three neighbouring sites, Ar1, Ar2 and Ar3 were trapped on the northern-faced slopes of the adiacent hill, but here Ditomus populations were found to be nearby absent or very small. The landscape is mainly characterized by a mosaic of extensively and intensively cultivated lands, and by sparse remnants of the pristine Quercus virgiliana forest. The observations have carried out in an uncultivated strip of olive trees lying at an altitude of 250-270 metres and measuring no more than $12,000 \mathrm{~m}^{2}$ (Fig. 3). This strip was abandoned for about 15 years and has been invaded by herbaceous plants like Inula viscosa and Daucus carota. The few trees are surrounded by a very dense herbaceous vegetation given by Avena barbata, Bromus (sterilis gr.), Tolpis umbellata, Hypochoeris radicata and Briza minor. Other main features are: southeastern aspect on a hill slope of $20^{\circ}$ steepness, soil evolved on a very clayrich river sediment, partly vertic, class 6 of the above classification. It dries out up to a depth of 1.5 metres during the summer dry season.

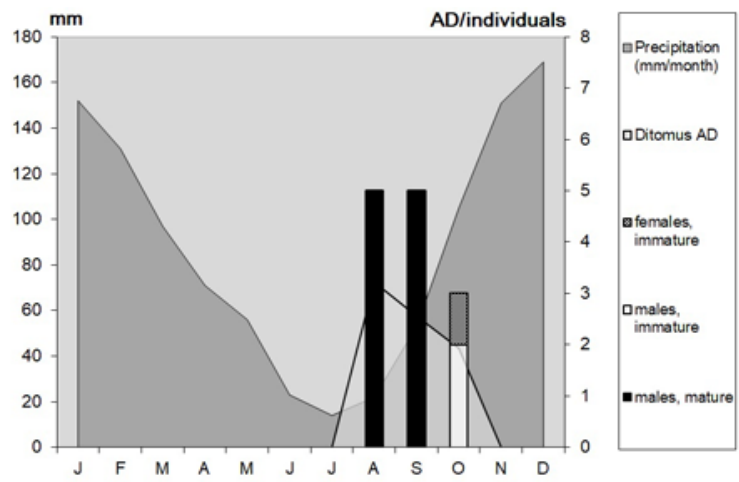

Fig. 2. Climatogram of the study area around Cosenza plotted against the Ditomus phenogram obtained $1989 / 90$ by pitfall trapping and the gonadal status of the 13 captured individuals (columns). The precipitation data (monthly medium values) have been found in Ciancio [1971].

Рис. 2. Климатограмма района исследований в окрестностях Козенца, сопряжённая с фенограммой D. calydonius, постоенной на основании репродуктивного статуса 13 особей, отловленных почвенными ловушками в 1989/90 гг. Среднемесячные значения осадков даны по Ciancio [1971].

The climate of Arcavacata is of the mediterraneantemperate type, with a mean annual temperature of 16.5 ${ }^{\circ} \mathrm{C}$, and $1000-1100 \mathrm{~mm}$ rain in the year, the dry period beginning around June and lasting until the end of September (Fig. 2). Site Ar4 was subdivided into four plots (Fig. 4), according to different ripening times of the host plant, Daucus carota. In the upper part of the hill slope (zone C, Fig. 4), the ripening of the food plant was accelerated during August and in this part of the study site 

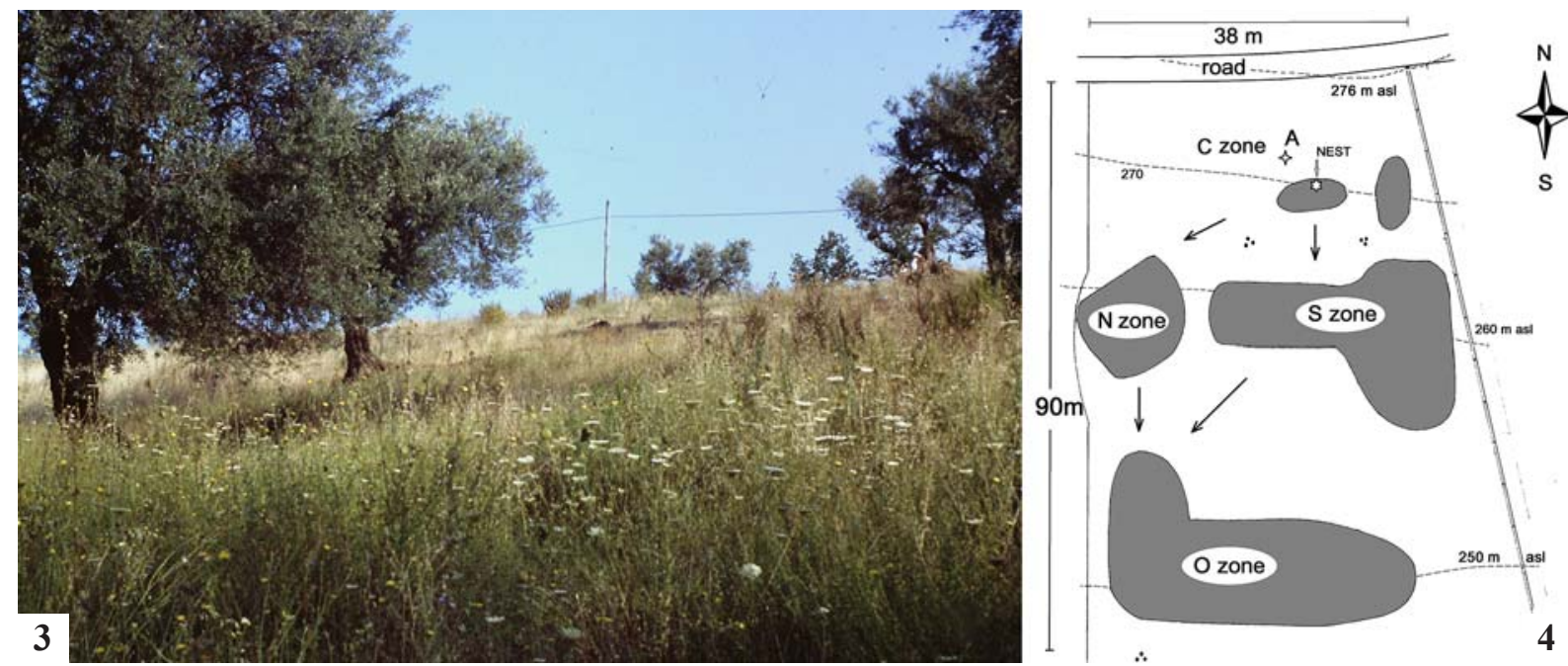

Figs 3-4. The study area: 3 - area Ar4 at Arcavacata seen from below (S zone), where the Daucus plants were still flowering (photo at end of July 1992); 4 - the four zones of Daucus development (C, N, S, O) corresponding to patches of maximum Daucus plant density (grey); A indicates the point of microclimate measurements; the star the position of the only nest-site found.

Рис. 3-4. Модельная площадка: 3 - площадка Ar4 в Аркаваката при виде снизу (зона S) с ещё цветущими растениями Daucus carota (конец июля 1992 г.); 4 - четыре зоны развития Daucus $(\mathrm{C}, \mathrm{N}, \mathrm{S}, \mathrm{O})$, соответствующие участкам с максимальной плотностью (серый цвет) растений; А - точка измерения микроклиматических параметров, звёздочка - положение единственного найденного гнезда.

Daucus plants grew more densely and showed shorter stalks, perhaps due to a combination of water deficit in the soil and higher ambient temperatures.

\section{Methods}

The carabid fauna of the 120 biotopes distributed along the principal transect was collected by a standard number of 6 (rarely 3-8) pitfall-traps, upper diameter of $9 \mathrm{~cm}$, depth: $11 \mathrm{~cm}$. Each plastic vessel was punched at two thirds from the bottom to avoid beetle "acquaplanning" after heavy rains, and was filled for a third of its volume with an attractive-conservant liquid given by wine vinegar with a very low percentage of formalin added (5\%). The traps were emptied monthly, the beetles identified and counted, the results expressed in indivduals/trap over the standard period of 10 days, calculated over the entire trapping season. This measure has called, as usual, "activity density" (AD). The survey lasted about 10 years, from 1988 to 1997, and allowed to check about 100.000 carabid beetles belonging to more than 160 species. The stands sampled were 45 forests (sclerophylls, oak, chestnut, black pine, beech forest), 6 brushlands, 22 pastures from mountains to Mediterranean, four abandoned croplands, 30 active cropland sites (18 olive orchards), 10 riverine biotopes and 7 badlands ("calanchi"). More data on species diversity found during this survey have given in Brandmayr et al., 1998, and in the works quoted there. General features, altitude, canopy covering and other data are stored in the Microsoft Excell file Carterus.xls, available in the laboratory of the authors.

Site Ar4 was firstly included in the general survey, together with sites Ar1, 2 and 3, and trapped from April 1989 to April 1990 by five pitfall traps. More detailed studies were conducted there during the years 1991-92, and the following observations made: a) Microclimatic measurements in the adult and larval microhabitats: daily air temperature measurements were made $1 \mathrm{~cm}$ above the soil surface, using minimax thermomethers 0.1 -scaled protected against incident radiation by a double aluminium shield. Soil temperature was measured at a depth of $10 \mathrm{~cm}$. The instruments were checked on an hourly basis during the population activity observations which were done every fourth day, at least for the first half of the night that corresponds to the main activity phase of the adults. Daily temperature cycles were obtained by measurements every hour during some days of study of the circadian locomotory rhythm (direct observations on host plants). Relative humidity was measured at $1 \mathrm{~cm}$ from the soil, with a Fischer's precision hair-hygrometer.

b) Foraging behaviour: feeding by beetles on Daucus inflorescences was monitored by direct observation using a red light source. Observations were made of foraging behaviour on the soil surface and on the food plants. A single nest entrance was found by tracking an individual beetle to a nest entrance on the night of August 21, 1992. The nest profile was reconstructed by careful digging. All other nest "entrances" investigated either belonged to other invertebrates or were unsused and invaded by ants.

c) Population size estimates, sex ratio, reproduction period and cycle. Counts of individuals were made within each of the four zones marked in Fig. 4 by transect counts of beetles made during the main period of night foraging, between 21.00 and 24.00 hour, every fourth night using the same standard path crossing each site. Some individuals (20 at all) were marked by a fine-pointed portable driller to ascertain the possibility of intrahabitat migration during the summer. Teneral individuals were recognized by their lighter colour, and it was possible to distinguish between "yellow" and "brownish-red" speci- 
mens of the new generation. The sexes were easily recognized even without lenses, although a small observation error was unavoidable, because some males in each population are known to be practically identical in size and shape to females. The frequency of these "feminine" individuals did not exceed a $2-3 \%$ of the whole population ("feminine" males show anyway a very short protuberance on the clypeus, not easy to ascertain in the field during the night observations).

In the laboratory the following observations were made:

a) All the specimens captured in pitfall traps of Stand Ar4 1989-90 were dissected to evaluate the status of gonadal development (13 specimens at all).

b) Five male-and-female pairs and mixed sex groups of 3-4 individuals were kept in small terrariums under temperature and light conditions similar to those measured in the field. Photoperiod was adjusted every three months to the external daily rhythm of light. Outside the laboratory, part of the terrarium boxes were exposed to external winter/spring conditions, protected against direct sun radiation from December to April.

c) The beetles were fed with ripe Daucus seeds, and after July 1992 with greenish, unripe Daucus umbels also, that were offered in an upright position forcing beetles to climb in order to harvest seeds.

d) Behavioural observations, under red light conditions, have made in a terrarium maintained on an inverted light/darkness cycle. The most useful behavioural observations run in a special "nest terrarium", measuring $50 \mathrm{~cm}$ by $70 \mathrm{~cm}$ depth, constructed with glass walls $5 \mathrm{~cm}$ apart. Eighteen beetles at all were used in laboratory observations.

We should finally emphasize that the greatest difficulty we encountered has been the collecting of alive individuals in sites apart from biotope Ar4, where the population study has carried out. Attempts made in an orchard not far from this site, regularly inspected by the first author, allowed the collecting of only 1-2 specimens in the year. Only pastures or garigues with dense Daucus patches allowed higher numbers. Stand Ar4 underwent regular tillage after 1993.

\section{Results and Discussion}

\section{Field results}

Habitat choice in Calabria

Data concerning the activity density of $D$. calydonius (individuals/trap in the standard period of $10 \mathrm{~d}$ ) have put against the canopy covering and soil clay content class of the stand trapped (Fig. 5). On a complex of 120 biotopes sampled, Ditomus has ascertained in six stands only, namely olive groves and abandoned cropland in the Crati Valley, and one extensive olive growth and a pasture on the Ionian Coast. Common features of the biotopes seem to be: low tree covering, high clay content of the soil, location at low height in the sclerophyll biome or in the neighbouring pubescent oak belt, the warmest vegetation belt of the deciduous biome, that occupies the most part of the calabrian elevations between 200 and 800 metres a.s.l. Any other kind of bedrock or soil seems to be fully avoided, but also on the Thyrrhenian coastal side some individuals have been found by direct collecting in a hilly situation, no more than 200 metres a.s.l. on clay rich soil.

Figure 5 visualizes the very "stenotopic" habitat affinity of $C$. calydonius in three dimensions. Selecting the only six stands marked by the presence of this carabid, a third factor could perhaps be enucleated, the slope aspect, being the populations living on north facing slopes the less abundant.

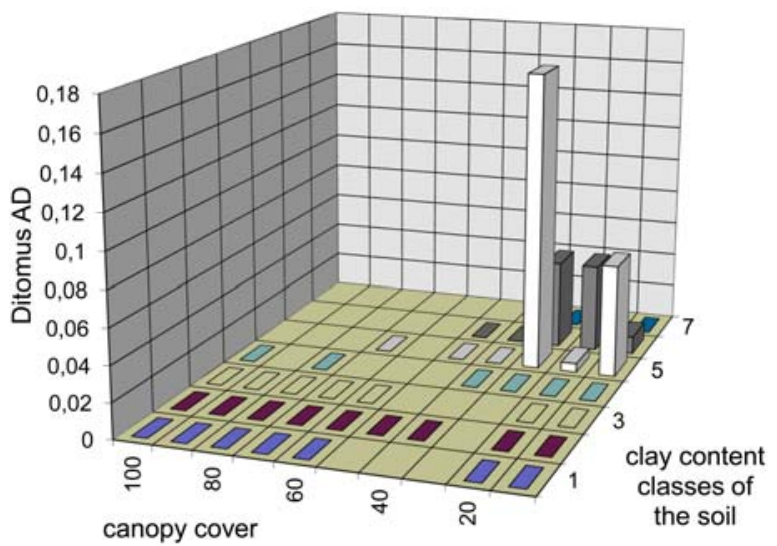

Fig. 5. Ditomus activity density (individuals/trap in the standard period of 10d) plotted against clay-in-the-soil-classes adopted in this study and canopy covering (\%). Note that Ditomus populations has been recorded by pitfall trapping only in class 5 and 6 , class 7 belongs to sodium chloride "blue clays" where Daucus plants show very little density.

Рис. 5. Динамическая плотность D. calydonius (особей / 10 ловушко-суток) в зависимости от типа почвы по составу глин и проективного покрытия в \% (обратите внимание, что популяции D. calydonius регистрировались почвеными ловушками только на почвах 5 и 6 классов, почвы 7 класса содержат хлориднонатриевые «голубые глины», на которых растения Daucus имеют очень низкую плотность).

Despite the low stand number, southern slope aspects (or level grounds) seem to favor Ditomus presence or activity. The complex of the Ar 1-4 stands, aligned along a valley cross section, with Ar2 and 3 closer to the valley bottom and on the northern slope, show that probably this species crowds on southern exposures, and that microrelief may be of great importance.

Other Ditomines living in the same valley were: Dixus obscurus Dejean, 1825, D. clypeatus (Rossi, 1790) and Carterus (Carterus) dama (Rossi, 1792).

Population study.

Annual activity pattern (phenology) and microclimate

The activity density of the first (trapping) year in biotope Ar4 is reported in Fig. 2, together with dissection data. Pitfall traps used 1989/90 and emptied monthly provided relatively small catches, perhaps because of the predominantly climbing habits of Ditomines. Perhaps for this reason they did not prove to be sufficiently effective for phenology studies of Ditomus. Anyway, 
Table 1. Activity density of $D$. calydonius in six stands with different altitude and exposure (Ar1 and Ar4 face each other on opposite hill slopes; TO11 and TP1 are also immediately adjacent biotopes in the Jonian coastal area).

Таблица 1. Динамическая плотность $D$. calydonius на шести модельных площадках, расположеных на разных высотах и экспозициях (Ar1 и Ar4 расположены напротив друг друга на противоположных склонах холма; TO11 и ТР1 непосредственно граничат друг с другом в прибрежной зоне Ионического моря).

\begin{tabular}{|l|l|c|c}
\hline \multicolumn{1}{|c|}{ stand } & aspect & altitude & $\begin{array}{c}\text { activity density } \\
\text { indiv. /trap /10 days }\end{array}$ \\
\hline Ar4 - abandoned cropland & SE & 250 & 0.064 \\
\hline Arl - aband. crop, sparse trees & NNW & 270 & 0.005 \\
\hline Arc4 - olive gr., natural, tilled & NNE & 240 & 0.005 \\
\hline Arc5 - olive gr., natural, untillled & E & 260 & 0.17 \\
\hline TO11 - extensive olive growth & - & 68 & 0.050 \\
\hline TP1 - Cynara pastureland & E & 100 & 0.010 \\
\hline
\end{tabular}

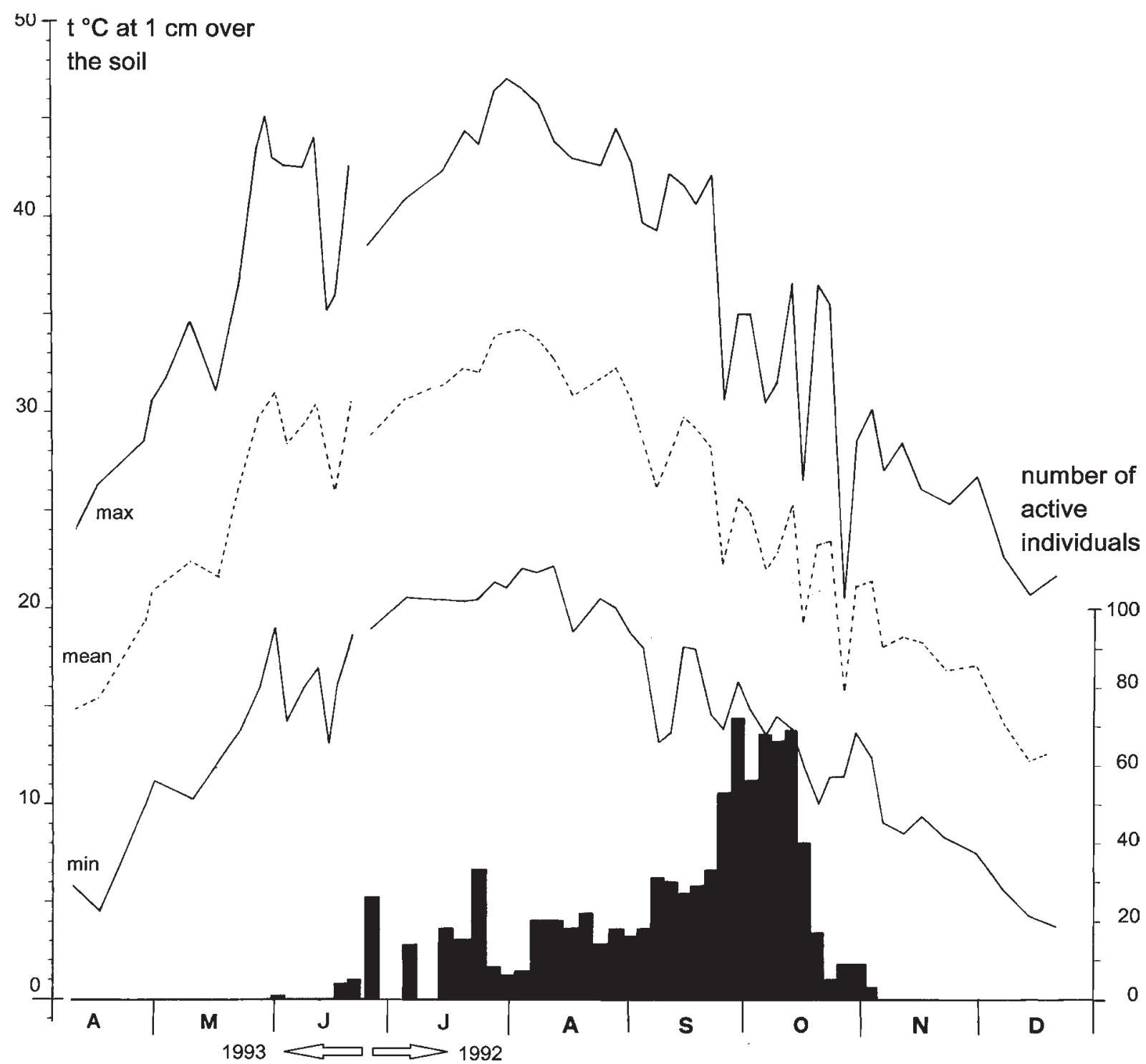

Fig. 6. Annual phenogram against temperatures of Ditomus population, counted as individuals active on Daucus umbellas every fourth day. Total data from the entire study area. Left ordinate: Maximum, mean and minimum temparature recorded at $1 \mathrm{~cm}$ from the soil surface.

Рис. 6. Годовая фенограмма популяции D. calydonius (суммарные данные для всего района исследований), составленная по результатам учётов жуков (раз в четыря дня), активных на зонтиках Daucus (левая ордината - максимальная, средняя и минимальная температура воздуха, зарегистрированная на расстоянии 1 см от поверхности почвы). 
they supplied the phenogram reported in figure 2 in which a high density peak of the population activity is shown to occur during some of the warmest and driest months (August-September) of the year.

Direct counts (1992/93) done on the Daucus umbels allowed a more reliable reconstruction of the activity period of the population (Fig. 5) as well as the identification of its occurence in the four subareas. The first individuals appeared in June, when the minimum night temperature was around $15^{\circ} \mathrm{C}$ and the maximum day temperature around $35-40^{\circ} \mathrm{C}$. The population was active up to the end of October, with a density peak resulting at the end of September, due to the newly emerged cohort (see below). Temperatures below or around $10^{\circ} \mathrm{C}$ (minima) seem to be incompatible with the climbing activity, and the beetles retire in short holes dug under stones for hibernation, when the soil temperatures (not reported) were still around $18^{\circ} \mathrm{C}$.

\section{Phenology and sex-ratio}

Population counts subdivided between males and females and plotted against relative humidity and mean air temperature of the hours ranging from 9 PM to 12 PM, i.e. at the time of maximum in daily activity have reported in Fig. 7. On this way a possible relationship between the "effective" microclimate and the movements of Ditomus adults can be observed. The relative humidity during the active phase of the population never dropped below $50 \%$ and laid most above $60 \%$. The real temperatures oscillated around $20^{\circ} \mathrm{C}\left(25-15^{\circ}\right)$, so we can argue that the individuals, in their natural habitat, are normally not exposed to extreme conditions and that the tenerals, less protected against desiccation, appear when air relative humidity was almost the highest of the year (October).

The seasonal variation of sex-ratio resulted to be remarkably evident because of the strong prevalence of females on the umbellas. The population, and especially the males, dropped to a minimum by the end of July due perhaps to cooperation in nest digging. The value oscillated around $50 \%$ in the first half of September (new generation feeding on inflorescences), while a strong prevalence of females was noted also in October, at least on the inflorescences, probably because females visited them more regularly.

Reproduction rhythm and new generation

The amounts of newly hatched individuals during the entire activity period as estimated through the colour of the specimen, were evaluated (Fig. 8). The first reddish tenerals appeared on August 12, but their number increased highly after September 18 , when probably many other nests were abandoned by the offspring. In October most individuals were immature while "old" specimens represented no more than a fourth of the population visiting the umbels. The fully yellow individuals were frequent in autumn, probably an avoidance of the desiccation risk related to the still too permeable integument.

The highest Ditomus individual number observed during one night (73) corresponds more or less to the "production" of three or four "normal" nests (considering both the number of pupal chambers found in the nest of this study, as well as the offspring number checked on the Tremiti Islands). The crowding of tenerals in October is a strong argument for a reproduction rhythm of the

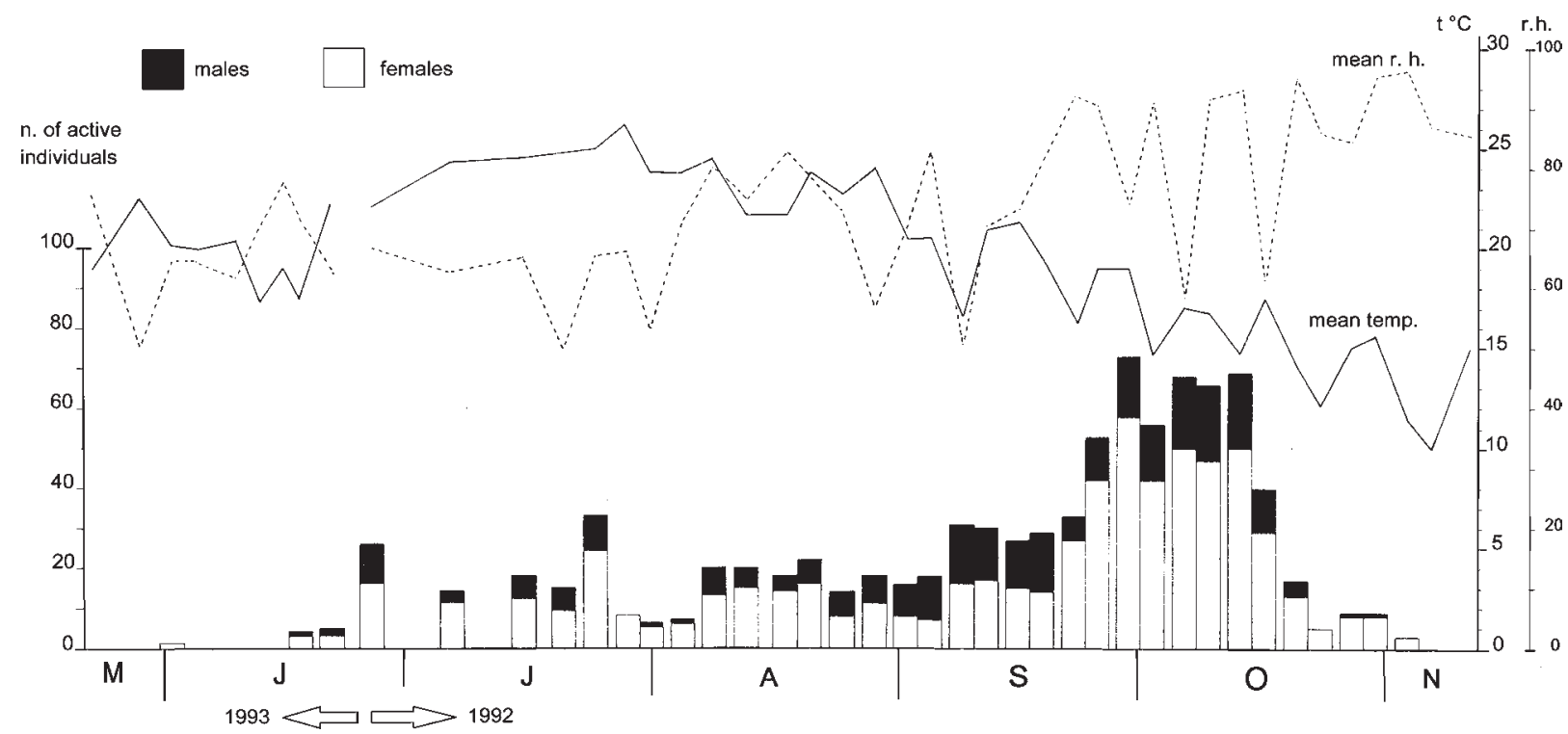

Fig. 7. Sex ratio of foraging population during the surface activity period. Right ordinates: temperature at $1 \mathrm{~cm}$ from the soil. Dashed line indicates the mean humidity, the continuous one the mean temperature observed in the first four hours of the night (mean of the recordings made every fourth day during the counts of foraging individuals).

Рис. 7. Соотношение полов в популяции D. calydonius в период фуражировки по данным напочвенной активности (правые ординаты - температура воздуха в 1 см от поверхности почвы (t.) и относительная влажность воздуха (r.h.); теаn r.h. — cредняя относительная влажность воздуха, mean temp. - средняя температура воздуха, наблюдаемые в первые четыре часа ночи; средние значения рассчитаны по результатам измерений в каждый четвёртый день при подсчёте кормящихся особей). 


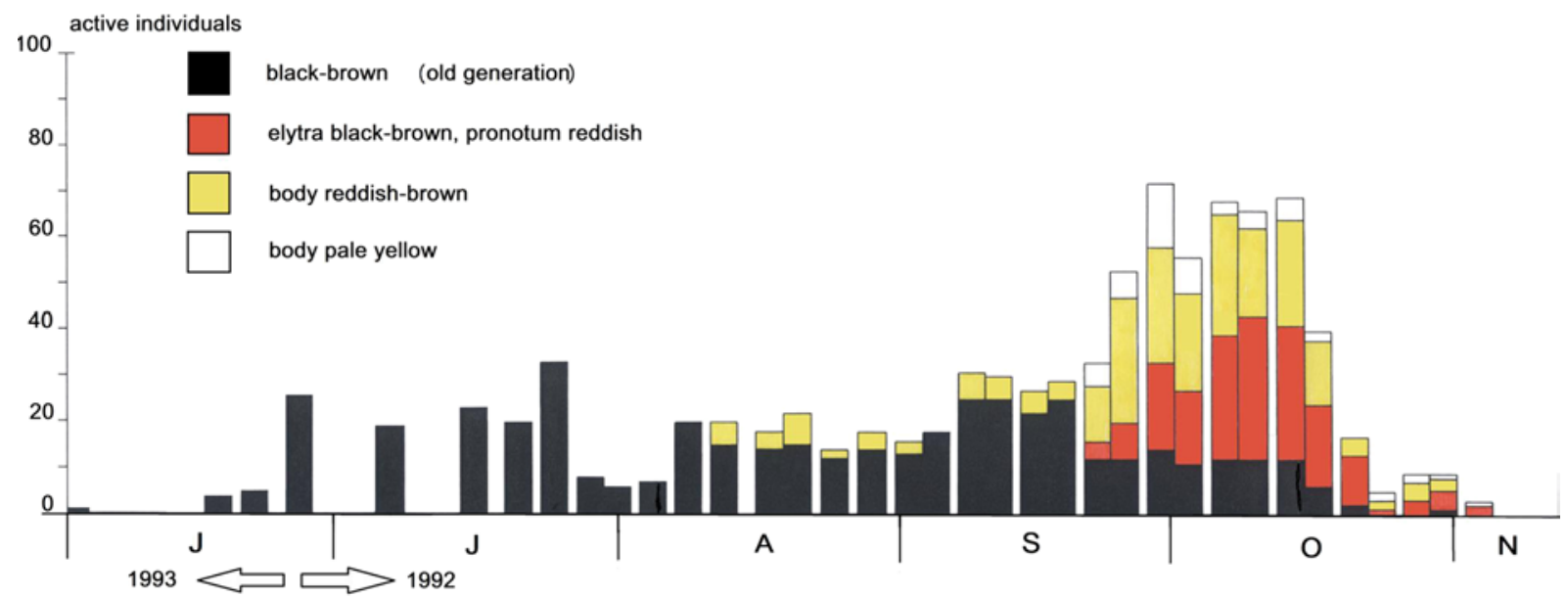

Fig. 8. Phenogram of Ditomus calydonius showing the new generation arousal and maturation level extimated by integument pigmentation.

Рис. 8. Фенограмма, демонстрирующая сроки появления и созревания новой генерации D. calydonius, исходя из степени пигментации покровов.

spring-breeder type [as in Larsson, 1939, Lindroth, 1949, Thiele, 1977]. Nevertheless, oviposition probably takes place very late, at least not earlier than July, so $D$. calydonius should be at best defined as a summer larvae species [as in den Boer, den Boer Daanje, 1990] with relatively short larval development.

\section{Daily activity rhythm}

The seed foraging behaviour of adult population was shown to be strictly nocturnal (Fig. 9), as displayed

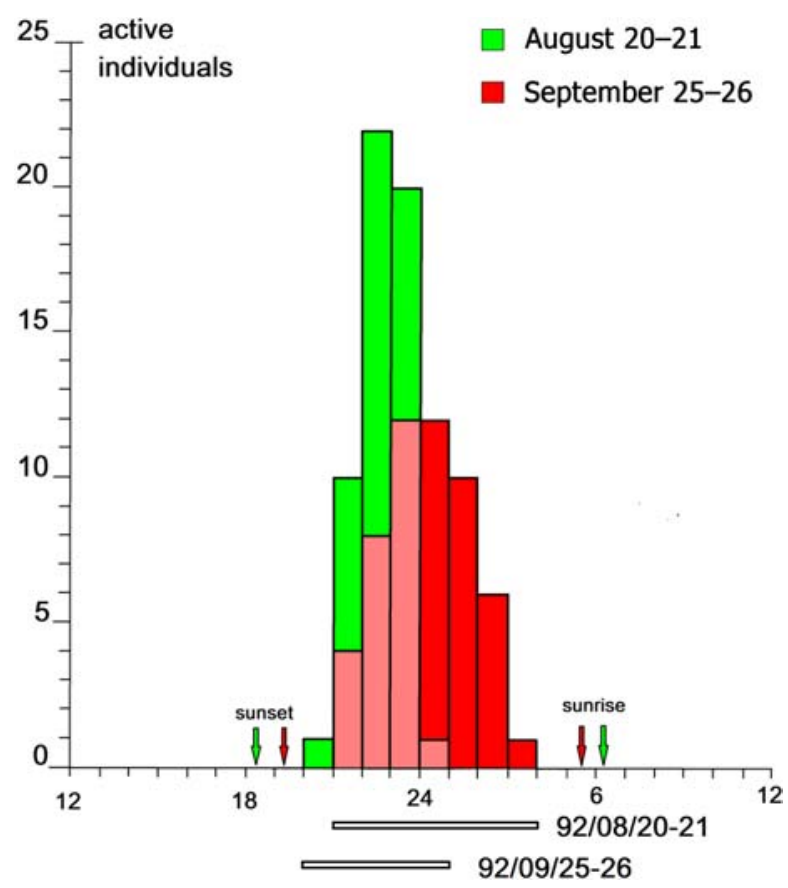

Fig. 9. Daily activity rhythm observed during two nights, Augus 20-21 and September 25-26, by visually inspecting the umbels every hour (all zones of the study area).

Рис. 9. Суточная активность D. calydonius, наблюдаемая в течение двух ночей 20-21 августа и 25-26 сентября, по результатам визуального осмотра зонтиков Daucus через каждый час (даные для всех исследованных зон). by the counts done in two different nights (August 2021 and September 25-26), with onset of beetle activity occurring normally two hours after sunset. In August the foraging activity lasted until 4 AM, in September only until midnight, probably because of lower night temperatures. The beetles always behaved as highly photophobic even under laboratory conditions.

Intrahabitat migration and nursing plant.

The observation of this part originated from the hypothesis that Ditomus feeds only on ripe Daucus seeds, although this idea had to be completely abandoned during our study, because we repeatedly saw vigorous feeding behaviours on green fruits while green, fragrant umbels seemed to be preferentially accepted by laboratory animals. In the four study areas (see Figs 34), a dense population was observed during June and July, along the warmest and driest section of the slope in the $\mathrm{C}$ zone. Only here, green seeds were available in July whereas lower in the valley the Daucus plants were still in its flourishing phase. In August, some individuals appeared outside the $\mathrm{C}$ zone (zones $\mathrm{S}, \mathrm{N}$ and $\mathrm{O}$ ), in the lower zone O several umbels were still "white" flourishing. At the same time, in $\mathrm{C}$ the first tenerals were found on the umbels, being a sure sign of successful nesting. In October the population "wave" peaked in zone $\mathrm{O}$, where immature individuals appeared more than one month later than in $\mathrm{C}$. The intrahabitat migration of the beetles has reported as separate curves in Fig. 10.

The observed population shift was tested by the recording of some previously marked individuals in the zone $\mathrm{O}$, but a quantitative estimate of the migrant fraction was impossible, for the marking procedure was highly invasive. Nevertheless, the intrahabitat migration probably plays a very important role for survival in the habitat, because it allows a better distribution of alimentary resources within the population itself, by ensuring precocious nesting females with sufficient nest supply and late emerging tenerals with enough food for the postpupation reserve building. Immature individu- 

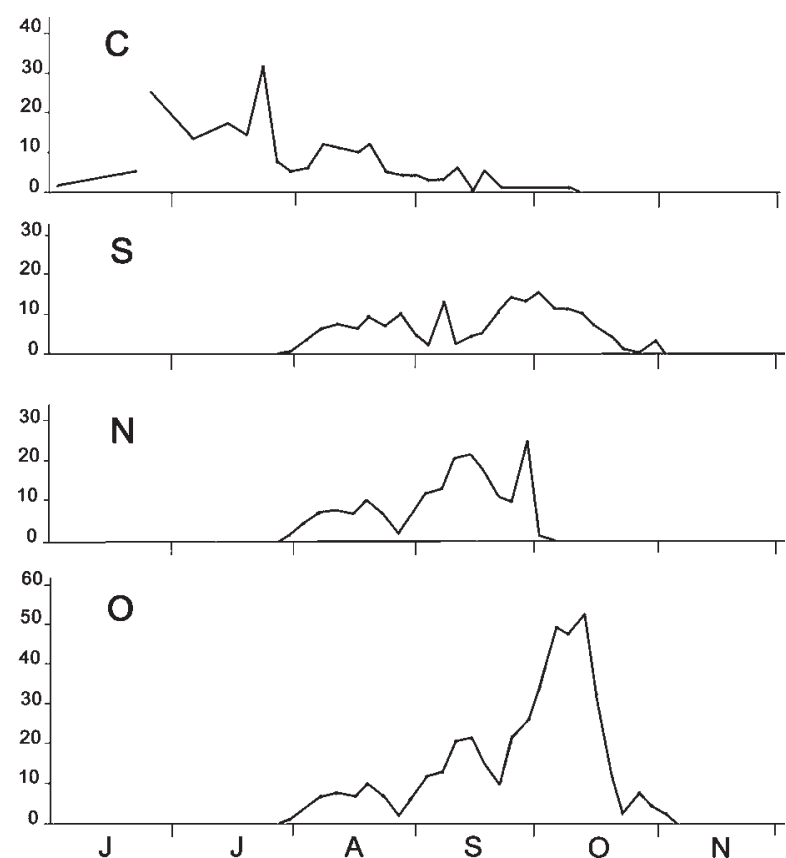

Fig. 10. Intrahabitat migration. Recordings of individuals in the four zones of the study area. Zone $\mathrm{C}$ was at the top of the slope, zone O $20 \mathrm{~m}$ height below, not far from the bottom of the valley.

Рис. 10. Миграция особей $D$. calydonius в пределах одного биотопа между четырьмя исследованными зонами (зона С - на вершине склона, зона О - на 20 м ниже, недалеко от дна долины).

als at the beginning of their activity either tended to remain near the nest or were observed in numbers of $5 / 6$ on the same flower, mostly together with a mature female. This behaviour lasts no more than few days.

\section{Nesting behaviour}

The only "true" nest was discovered August 21 in the field, by observing the foraging behaviour of a female. The beetle transported with its mandibles a secondary umbel containing a certain number of fruits and descended the Daucus stem with the head pointed downwards. The nest entrance was placed at only $50 \mathrm{~cm}$ from the stem, masked by numerous plant rests. The mother deposited its load near the nest hole, after having completed some circular movements around it and disappeared inside for more or less one minute. Thereafter the beetle reappeared and pulled back the whole umbella into the nest. This subterranean lodge is described in Fig. 11. The mother was found in the first lateral gallery, with the last Daucus supply beneath, together with three immature specimens (two females and one male) at a medium depth (about $12 \mathrm{~cm}$ ), another teneral male at about $22 \mathrm{~cm}$. Finally, an oblique gallery ended at $37 \mathrm{~cm}$. About 10 centimetres from the bottom, part of the nest was occupied by conspicuous Daucus reserves and fruit remnants. The transversal nest branches were $1 \mathrm{~cm}$ high and $2-3 \mathrm{~cm}$ broad and very likely they hosted pupal cells (on the Tremiti Islands the nest sheltered 26 larvae and/or pupae). At least 18 pupal shelters were recognizable at all.

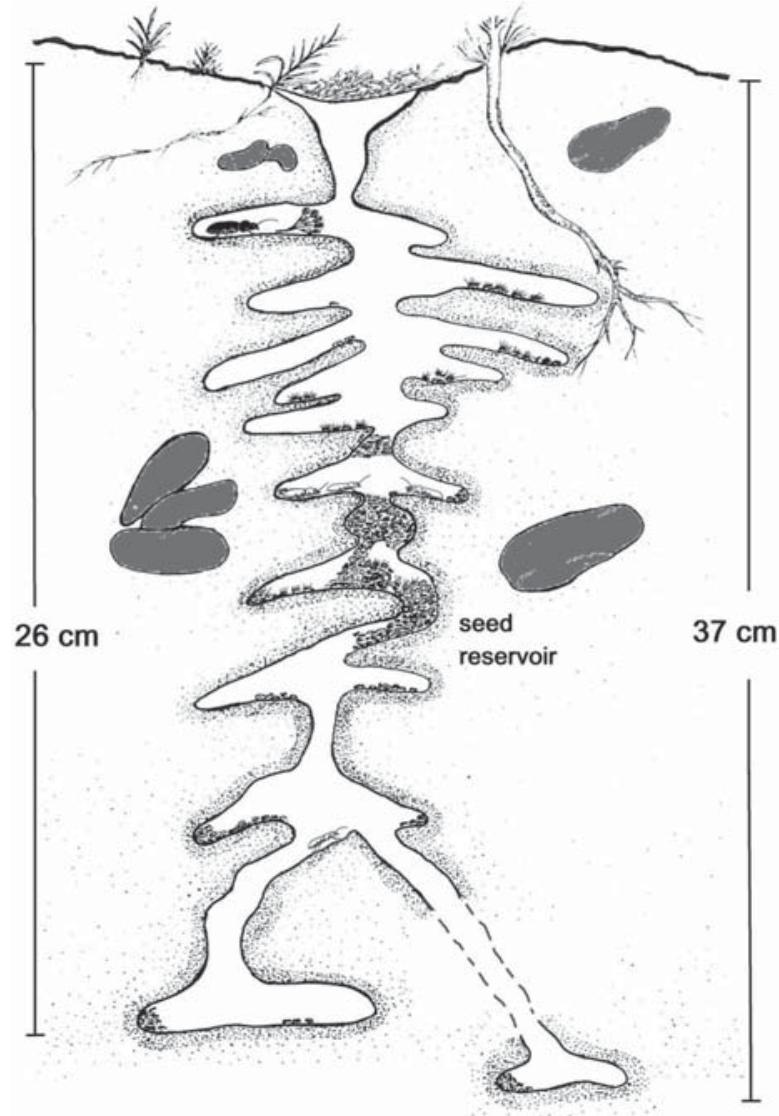

Fig. 11. Profile of the nest found at August, 21, 1992 in the C zone. All the specimens found are represented in their own position. (Original drawing by dr. Erminio Rocca).

Рис. 11. Профиль гнезда D. calydonius, найденного 21 августа 1992 г. в зоне C (все экземпляры представлены на месте обнаружения; оригинальный рисунок доктора Эрминио Рокка).

Some other important aspects of behaviour should be emphasized.

Nest provisioning occurs during the entire nest life and every night the mother is forced to strengthen nest supplies since the rapid larval development during the high summer temperatures requires day-by-day foraging.

The mother improves foraging efficiency by detaching entire secondary umbels and by doing so loads of 612 fruits are carried into the nest during one foraging trip.

During the nesting period a part of the population, perhaps a younger cohort, continued to feed on inflorescences but only single fruits were taken away so that the "skeletons" of the secondary umbels remained on the plant; the presence of foraging females in an area seems to be supported by cut-off secondary umbels [see also Brandmayr, Brandmayr Zetto, 1974].

The feeding behaviour of adult Ditomus is still poorly known. It can occur either on the outer surface of umbellas, or also inside, as it has been observed for some Ophonus species (in the study area: O. ardosiacus (Lutshnik, 1922), O. puncticeps Stephens, 1828). A detail of the consumatory act was found to be really unusual among beetles (Fig. 11): adults of both sexes were able, in a similar fashion to rodents, to hold the fruits with the 


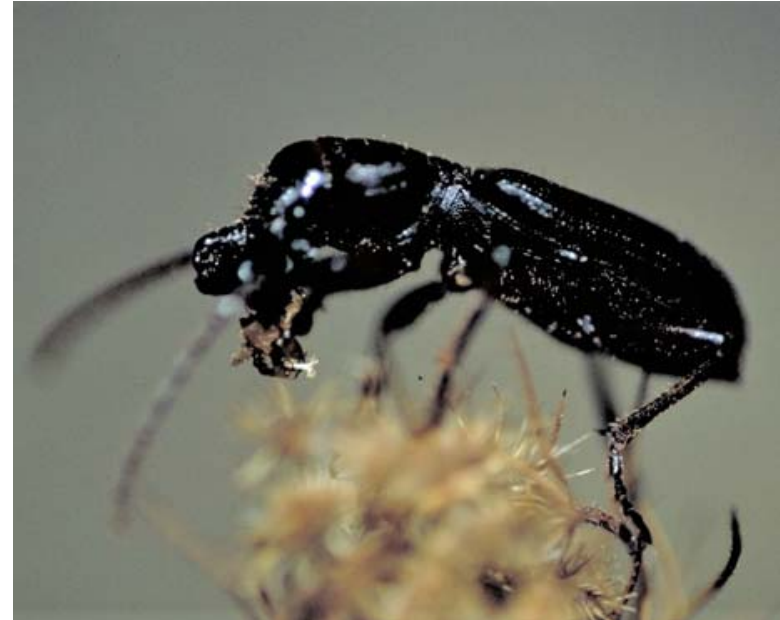

Fig. 12. A male of Ditomus calydonius on a Daucus inflorescence, showing the typical feeding position, i. e. holding a seed between the forelegs.

Рис. 12. Самец D. calydonius на соцветии Daucus в типичной позе в момент питания - держит семя между передними лапками.

front legs, on this way probably the removal of seed envelopes is possible [as seen in larvae of Ophonus puncticeps, Brandmayr Zetto, Brandmayr, 1975].

\section{Laboratory results}

As far as the laboratory study is concerned, it was necessary to prolong the observations to more than two years. In any case it was only possible to report the results in a shorten form since two years rearings did not prove to be sufficient to clarify the conditions necessary for successful reproduction. Among five pairs of beetles studied, just one reproducted in the second year of life after pro- longed exposition to natural temperature conditions. The laboratory nest (1993, July, 27) presented a simple structure on the account of its limited dimensions. There was an unique entrance leading to an upper gallery furnished with some stored Daucus seeds that contained the male who never cooperated in seed foraging. In two other deeper galleries it was possible to find the mother with three newly hatched adults with the hole below being still shared by a young pupa. From the activities displayed by the beetles it seems that the male exerts only the role of nest excavator, the female on the contrary was actively foraging the nest. The offspring achieved the final pigmentation in about 10 days, and September 7 mating behaviour was observed with a 7 minutes lasting copulation.

Flight behaviour was only observed in June, three males and five females were engaged in short flights of $10-12 \mathrm{~cm}$, normally announced by intense movements of the median and posterior legs, and by vibrations and quivering of the elytra.

Mating behaviour has rarely been observed (only twice) with copulatory activities lasting no longer than 7-10 minutes.

Inter-male fightings, which had also only rarely observed, occurred between two males maintained in the same terrarium. The encounters have always provoked by the smaller individual, with less pronounced head protuberances, and they took place both on the ground surface and on the Daucus umbels. The fighters faced each other raising the front legs and butting the thorax sternites, while the mandibles had frenetically opened. In these nine encounters the smaller individual was the winner 7 times, indicating probably a greater degree of sexual maturity, since after the introduction of a female he was the only one that displayed a mating

Table 2. Summary of the observations on behaviour made on 17 specimens of D. calydonius in two years (about 1200 hours of visual checking spread over 17 months), kept in terrarium (subdivided in five couplets and in two additional groups of three and four individuals).

Таблица 2. Результаты двухлетних наблюдений (1200 часов визуализации в течение 17 месяцев) за поведением 17 особей $D$. calydonius, содержавшихся в террариуме (пять пар и две дополнительные группы по три и четыре особи).

\begin{tabular}{|c|c|c|c|}
\hline Behaviour type & Terrarium and/or mode & Number of times & Time of the day \\
\hline $\begin{array}{l}\text { Food uptake } \\
\text { (Daucus seeds) }\end{array}$ & $\begin{array}{l}\text { All specimens ( } 17) \\
\text { After July' } 92 \text { only with green or } \\
\text { fresh umbels }\end{array}$ & $\begin{array}{l}\text { 1-2 times per night, } \\
\text { mostly every night }\end{array}$ & $\begin{array}{l}\text { Old adults: only at } \\
\text { night. Tenerals: also in } \\
\text { the light phase }\end{array}$ \\
\hline Flight (attempts) & $\begin{array}{l}\text { Only in June and July, after } \\
\text { intensive exploration and elytra } \\
\text { quivering - } \\
\text { temperature } 26-31{ }^{\circ} \mathrm{C}\end{array}$ & $\begin{array}{l}\text { Males: } 5 \text { times } \\
\text { Females: } 3 \text { times }\end{array}$ & Light phase \\
\hline Inter-male fighting & $\begin{array}{l}\text { Terr. } 1,2 \text { males }+1 \text { female, } \\
\text { on the soil or within the umbels }\end{array}$ & $\begin{array}{l}\text { Several evenings from } \\
\text { June } 4 \text { to June } 30\end{array}$ & Beginning of the night \\
\hline Copulation & $\begin{array}{l}\text { Terr. } 1 \text {, between the smaller male } \\
\text { and the newly introduced female } \\
\text { (June } 30 \text { ) }\end{array}$ & $\begin{array}{l}\text { Two at all, the second } \\
\text { between two tenerals one } \\
\text { month after pupation } \\
\text { (September } 7 \text { ) }\end{array}$ & \\
\hline Nesting & $\begin{array}{l}\text { Terr. 5, } 1 \text { couplet; nest dug out } \\
\text { June of the second year ( } 1993 \text { ) } \\
\text { offspring: } 4 \text {, at July } 27 \text { three } \\
\text { tenerals ( } 2 \hat{\partial}, 1 q) \text {, and one } \\
\text { pupa }\end{array}$ & $\begin{array}{l}\text { One couplet of five kept } \\
\text { in } 5 \text { small terrariums }\end{array}$ & \\
\hline
\end{tabular}


behaviour. The nine fightings observed lasted from 6 to 20 minutes, on average about 10 minutes.

Male fightings in Carabids are known only from Scaritinae, and well described only for Scarites buparius (Förster, 1771). This species is a very aggressive and efficient predator that uses its mandibles not only for predation, but also in between-males combats, which end normally with the escape of the less robust individual [Talarico et al., 2018].

\section{Conclusions}

Field data concerning the habitat selection of $D$. calydonius speak in favour of a highly stenotopic beetle, which concentrates on fully unshadowed, sun-exposed clayey soils, but only in presence of a dense Daucus covering. The habitat with the highest activity density is the site where the population study has carried out, here the food plant population showed a very early ripening in late spring, a condition that probably is in favour of successful Ditomus reproduction. The previous hypothesis (see introduction), about the importance of availability of ripe Daucus seeds seems no more sustainable, as it is demonstrated by the simple evidence that after June also no ripe seeds are found on the umbels, and that the whole July population is foraging and feeding on green inflorescences, greenish-red in colour (Fig. 13). From this point of view, the presence of Daucus appears to be a necessary (but not sufficient) condition, because the determinant factor is the early ripening of this plant, in the more or less "dwarf" form described at page 458. This could explain the observed stenotopy of $D$. calydonius, and its concentration on southern slopes. The importance of the key factor "clay fraction in the soil" is probably explained by the need to excavate a nest as deep as possible in June, immediately after the end of the mediterranean "rain season". In July the soil dries out and becomes of stony hardness.

The field data gathered for this carabid are indicative of a spring breeder (or summer larvae-breeder) that requires above all very high soil temperatures but also other particular habitat conditions such as food with the consequential shifting of reproduction to late summer. Even though the population phenogram resembles more an autumn breeder of type 3 [Paarmann, 1979], the crowding of immature specimens in autumn, together with the late onset of nesting possibilities excludes any possible hypothesis of "winter larvae". A first evidence of very short larval development has obtained in laboratory, with a larval development no longer than 45 days at $26^{\circ} \mathrm{C}$.

On the basis of the paedotrophic nest being supplied with seeds day by day (fractioned provisioning), a winter or autumn reproduction is hardly sustainable, because an extremely long period of brood care enhances enormously the risk of a precocious death of the mother by predators or adverse wheather conditions with the subsequent death of the fully mother-dependent larvae. The strictly nocturnal activity also supports the idea of adults with inadequate protection against predators. Moreover, unlike other Carabidae, most Ditomines do not exhibit aposematic colours nor strong defensive secretions.

Other Daucus-tied Harpalines, such they are found for example in Ophonus Dejean, 1821 [Zetto Brandmayr, 1983; Brandmayr, Zetto Brandmayr, 1982; Talarico et al., 2016] are all autumn breeders, probably as a consequence of their larvae need to feed on large amounts of seeds that are released by Daucus umbels in

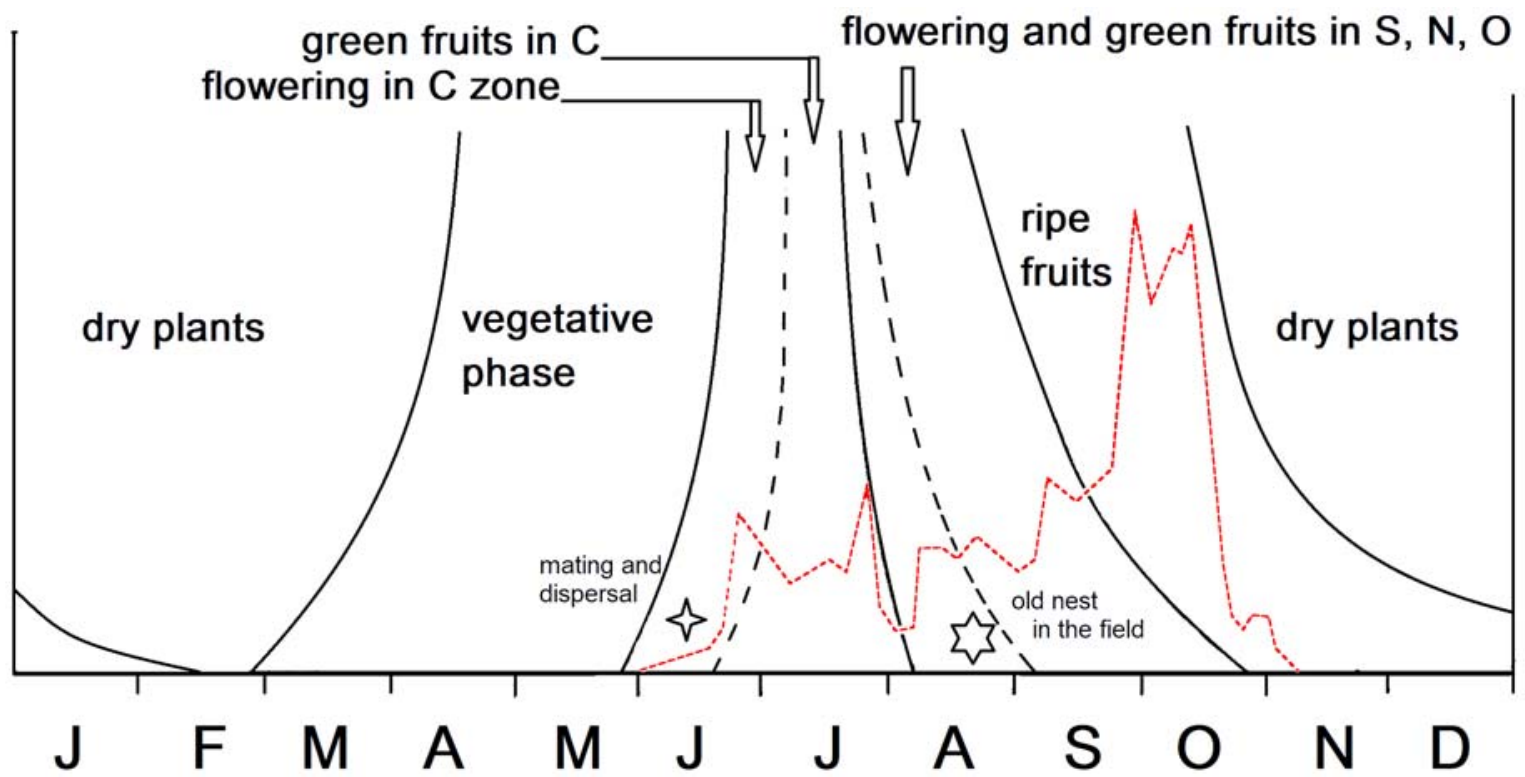

Fig.13. Distribution in the year of Ditomus population activity (dotted line) compared with the phenogram of thevegetative phases of Daucus carota.

Рис.13. Годовая динамика активности D. calydonius (пунктирная линия) сопряжённая с фенограммой вегетативных фаз Daucus carota. 
this season. The phylogenetically related Ditomines "have acquired the ability" to transfer the Daucus fruit foraging into subterranean nests, more or less protected by the strong summer aridity of the mediterranean climate.

Figure 13 provides a reliable image of the population cycle of this ground beetle and of the relationships with the main feeding plant (Daucus carota). In addition, some interesting laboratory data dealing with the possible dispersal phase in June have been included. This period of flying could be of considerable importance for the already mentioned need of reproduction sites where Daucus fruits ripen very early in the season. Anyway, we cannot exclude the possibility that in other countries, D. calydonius populations are able to forage on other umbel plants, untill now unknown.

In the study area of Arcavacata, the existence of early ripening habitat patches where Daucus seeds were available no later than the end of June has ascertained. This aspect maybe related also to the observed intrahabitat micromigrations, which could be the counterpart of the early site choice of the nesting "families". This phenomenon could be the reason for newly emerging individuals of younger nests are forced to migrate to less exploited pathches, where secondary umbels have not yet been cut down by foraging females or occupied by spiders or other competitors.

Many aspects of $D$. calydonius biology remain unclear, among them the behavioural details of the initial phases of nesting and of mate choice, the reproduction rates and the factors controlling reproduction rhythms. Further investigation on these subsocial carabid beetles could teach us how a strictly predatory and non-social family was able to shift to subsociality mediated by newly acquired granivorous habits.

The Ditomines represent so far the only Adephagan stock of Coleoptera in which generation overlapping has ascertained, adult sexual dimorphism and larval morphology resemble habits and behaviour of some Polyphagan families, e.g. in the dung beetles (Scarabaeoidea), even if the food here is represented by cow or horse droppings [Tonelli et al., 2021]. The possibility of food relocation and conservation seems a basic "exhaptation" that favours the appearance of subsocial behaviours [Halffter, 1991].

Acknowledgements. The Authors are very grateful to two students, Franca Puzzo and Erminio Rocca, who cared for field observations and laboratory rearings during their graduate thesis at the University of Calabria. Research financed by the Italian Ministry for Scientific Research (MIUR) on the $60 \%$ fraction.

Competing interests. The authors declare no competing interests.

\section{References}

Alicata P., Caruso D., Costa G., Marcellino I., Motta S., Petralia A., 1980. Ricerche eco-etologiche sulla fauna delle dune costiere di
Portopalo (Siracusa). III. Comportamento e ritmi di attività di Scarites buparius Forst. (Coleoptera, Carabidae) // Animalia. Vol.7. P.5-21.

Antoine M. 1959. Coléoptères Carabiques du Maroc (III). Harpalidae // Mem. Soc. Sci. Nat. Phys. Maroc, Zoologie. N.S. Vol.6. P.315-465.

Brandmayr P. 1975. Note morfologiche sugli stadi preimmaginali di Carterus (Sabienus) calydonius Rossi (Col., Carabidae) // Boll. Soc. Ent. Ital. Vol.107. P.9-19.

Brandmayr P. 1992. Short review of the presocial evolution in Coleoptera // Ethology, Ecology \& Evolution. Special Issue. Vol.2. P.7-16.

Brandmayr P., Brandmayr Zetto T. 1974. Sulle cure parentali e su altri aspetti della biologia di Carterus (Sabienus) calydonius Rossi, con alcune considerazioni sui fenomeni di cura della prole sino ad oggi riscontrati in Carabidi (Coleoptera, Carabidae) // Redia. Vol.55. P.143-175.

Brandmayr P., Zetto Brandmayr T. 1982. Communità a Coleotteri Carabidi di alcuni Querco-arpineti della bassa pianura del Friuli // Quad. C.N.R. Str. Zooc. Terr. Vol.4. P.69-124.

Brandmayr P., Pizzolotto R., Zetto Brandmayr T. 1994. Population biology and nesting of Carterus calydonius Rossi (Coleoptera, Carabidae, Ditomini) // Boll. Zool. Suppl. P.50-51.

Brûlerie C.P. de la. 1873. Monographie des Ditomides // L'Abeille. Paris. Vol.11. P.i-viii, 1-100.

Ciancio O. 1971. Sul clima e sulla distribuzione altimetrica della vegetazione forestale in Calabria // Ann. Ist. Selvicoltura, Arezzo. Vol.2. P.321-370

Crowson R.A. 1981. The biology of the Coleoptera. London: Academic Press.

den Boer P.J., den Boer-Daanje W. 1990. On life history tactics in carabid beetles: are there only spring and autumn breeders? // Stork N.E. (ed.). The Role of Ground Beetles in ecological and environmental studies. Andover-Hampshire: Intercept Publishers. P.247-258.

Eickwort G.C. 1981. Presocial Insects. In: Herman H.R. (ed.) Social Insects. Vol. II. Academic Press, New York, London. P.199-280.

Halffter G. 1991. Feeding, bisexual cooperation and szubsocial behavious in three groups of Coleoptera // Zunino M. et al. (eds.). Advances in Coleopterology. Barcelona: European Association of Coleopterology. P.281-296.

Larsson S.G. 1939. Entwicklungstypen und Entwicklungszeiten der dänischen Carabiden // Entom. Medd. Vol.20. P.277-554.

Lindroth C.H. 1949. Die Fennoscandischen Carabidae III // Kungl. Vetensk Vitterh. Samb. Handling, Goteborgs. Ser.B. Bd.4. No.3. S.1-911.

Paarmann W. 1979. Ideas about the evolution of the various annual reproduction rhythms in Carabid beetles of the different climatic zones // Misc. Pap. Landbouwhogesch. Wageningen. Vol.18. P.119-132.

Pellissier-Scott M. 1990. Brood guarding and the evolution of parental care in burying beetles // Behav. Ecol. Sociobiol. Vol.26. P.31-39.

Reyes-Castillo P., Halffter G. 1984. La estructura social de los Passalidae (Coleoptera, Lamellicornia) // Folia Entomologica Mexicana. Vol.61. P.49-72.

Sharova I.Kh. 1958. [The larvae of Carabidae, beneficial and noxious to agriculture] // Uchenye Zapiski Moskovskogo gorodsk. Pedagog. Inst. Vol.124. P.1-165 [in Russian].

Sharova I.Kh.1960. [Morpho-ecological Types of Carabid larvae] // Zool. Zhurn. P.691-708 [in Russian].

Sharova I.Kh., Makarov K.V. 1983. [Larvae of the Machozetus lehmanni Men. (Coleoptera, Carabidae)]//Entom. Obozr. Vol.62. No.3. P.524-528 [in Russian].

Stichel W. 1923. Zur Phylogenesis eines geologisch jungen Formenkreises der Käfer, der Ditominen (Carab. Harpal.) // Z. wiss. Insektenbiol. Vol.18. P.51-60; 81-100; 145-162; 209-242.

Talarico F., Cavaliere F., Mazzei A., Brandmayr P. 2018. Morphometry and eye morphology of three scaritine ground beetles relate to habitat demands and behavioural traits (Coleoptera, Carabidae, Scaritinae) // Zoologischer Anzeiger. Vol.277. P.190-196.

Talarico F., Giglio A., Pizzolotto R., Brandmayr P. 2016. A synthesis of feeding habits and reproduction rhythm in Italian seed- 
feeding ground beetles (Coleoptera: Carabidae) // European Journal of Entomology. Vol.133. No.1. P.325-336.

Thiele H.U. 1971. Die Steuerung der Jarhresrhythmik von Carabiden durch exogene und endogene Faktoren // Zool. Jb. Syst. Vol.98. P.341-371.

Tonelli M., Giménez Gómez V.C., Verdú J.R., Casanoves F., Zunino M. 2021. Dung Beetle Assemblages Attracted to Cow and Horse Dung: The Importance of Mouthpart Traits, Body Size, and Nesting Behavior in The Community Assembly Process // Life. Vol.11. P.873. https://doi.org/10.3390/life11090873

Wilson E.O. 1971. The Insect Societies. Cambridge: Belknap Press of Harvard Univ. Press. 562 pp.

Wilson E.O. 1979. Sociobiologia. La nuova sintesi. Bologna: Zanichelli. 688 pp.

Zetto Brandmayr T. 1983. Life cycle, control of propagation rhythm and fecundity of Ophonus rotundicollis Fairm. et. Lab. (Co- leoptera, Carabidae, Harpalini) as an adaption to the main feeding plant Daucus carota L. (Umbelliferae) // Brandmayr P., den Boer P.J., Weber F. (eds.). The synthesis of field studies and laboratory experiment. Report of the $4^{\text {th }}$ meeting of European Carabidologists, 'Haus Rothenberge', Westphalia Bundesrepublik Deutschland, September 24[150]26, 1981. Wageningen: Centre for Agricultural Publishing and Documentation (PUDOC). P.93-103.

Zetto Brandmayr T., Brandmayr P. 1975. Biologia di Ophonus puncticeps Steph. Cenni sulla fitofagia delle larve e loro etologia (Coleoptera, Carabidae) // Ann. Del. Fac. Sci. Agrar. Del. Univer. Deg. Studi Torino. Vol.9. P.421-430.

Zetto Brandmayr T., Puzzo F., Rocca E. 1994. Further observations on parental behaviour in Carterus (Sabienus) calydonius Rossi (Coleoptera, Carabidae) // Bollettino di zoologia. Poster session. Suppl.61. P.59. DOI: $10.1080 / 11250009409356006$. 